\title{
Pengaruh pertumbuhan ekonomi terhadap penyerapan tenaga kerja dan kemiskinan di Kabupaten Sarolangun
}

\author{
Muhammad Sokian*; Amri Amir; Zamzami \\ Prodi Magister Ilmu Ekonomi, Program Pascasarjana, Universitas Jambi \\ *E-mail korespodensi: aschandra22@gmail.com
}

\begin{abstract}
This study aims to analyze the effect of economic growth on employment in Sarolangun Regency, and to analyze the effect of economic growth and employment on poverty levels, poverty depths and poverty severity levels in Sarolangun District. The data used in this empirical study are secondary data from the 2001-2017 time series originating from the Central Statistics Agency (BPS) and the Central Statistics Agency of Sarolangun Regency. The analysis method used in this research is descriptive analysis and path analysis. The results showed that economic growth had no significant effect on the dependent variable of labor. Any increase or decrease in economic growth does not affect the increase or decrease in the number of workers in the Sarolangun Regency. Economic growth has a negative direction and has a significant impact on poverty levels, poverty depth, and poverty severity through the workforce in Sarolangun District
\end{abstract}

Keywords: Poverty rate, Economic growth, Labor

\begin{abstract}
Abstrak
Penelitian ini bertujuan untuk menganalisis pengaruh pertumbuhan ekonomi terhadap lapangan kerja di Kabupaten Sarolangun, dan menganalisis pengaruh pertumbuhan ekonomi dan lapangan kerja terhadap tingkat kemiskinan, kedalaman kemiskinan dan tingkat keparahan kemiskinan di Kabupaten Sarolangun. Data yang digunakan dalam penelitian empiris ini adalah data sekunder dari seri waktu 2001-2017 yang berasal dari Badan Pusat Statistik (BPS) dan Badan Pusat Statistik Kabupaten Sarolangun. Metode analisis yang digunakan dalam penelitian ini adalah analisis deskriptif dan analisis jalur. Hasil penelitian menjelaskan bahwa pertumbuhan ekonomi tidak berpengaruh signifikan terhadap variabel dependen tenaga kerja. Setiap kenaikan atau penurunan pertumbuhan ekonomi tidak mempengaruhi kenaikan atau penurunan jumlah pekerja di Kabupaten Sarolangun. Pertumbuhan ekonomi memiliki arah negatif dan memiliki dampak signifikan pada tingkat kemiskinan, kedalaman kemiskinan dan keparahan kemiskinan melalui tenaga kerja di Kabupaten Sarolangun.
\end{abstract}

Kata kunci: Tingkat kemiskinan, Pertumbuhan ekonomi, Tenaga kerja

\section{PENDAHULUAN}

Kemiskinan merupakan salah satu masalah dalam perekonomian yang kompleks dan multidemensi. Masalah kemiskinan menjadi hal yang sangat serius dan menjadi masalah bagi daerah yang kondisi perekonomiannya tertinggal jauh. Strategi Pembangunan yang hanya berorientasi pada pertumbuhan ekonomi yang menimbulkan suatu realita yakni kemiskinan yang tampak jelas. Seiring pertumbuhan ekonomi serta kesejahteraan rakyat yang hanya mengandalkan kemanpuan fisik dan pola fikir yang 
menjadikan masyarakat tidak memiliki pandangan yang dapat mendorong peningkatan terhadap ekonomi melalui "Human Capital", dan tidak dapat diingkari bahwa pada kenyataannya siapapun yang terjebak dalam kemiskinan akan sangat sulit mengejar ketertinggalan.

Dalam mencapai tujuan pembangunan, kemiskinan harus dapat dikendalikan. Kemiskinan merupakan fokus utama dalam tujuan dokumen pembangunan, misalnya tertuang pada Rencana Pembangunan Jangka Menengah (2004-2009) yang disusun berdasarkan Strategi Nasional Penanggulangan Kemiskinan (SNPK). Dalam RPJM pemerintah menyusun tujuan pokok dalam pengentasan kemiskinan untuk tahun 2014. Selain itu juga sejalan dengan tujuan RPJMN (Rencana Pembangunan Jangka Menengah Nasional) yakni didasarkan pada kerangka pembangunan Jangka menengah ketiga (2014-2019) secara ekonomi dan social, bangsa Indonesia, ingin tingkat kesejahteraan yang terus meningkat dan berkelanjutan, yang dinikmati oleh banyak penduduk diseluruh Indonesia dengan kesenjangan menurun. Beberapa hal yang menjadi fokus utama, yang pertama potensi ekonomi Indonesia yang demikian besar harus dapat direalisasikan dalam bentuk pertumbuhan ekonomi yang tinggi, yang menghasilkan lapangan kerja dan mengurangi kemiskinan. Kemajuan bangsa dalam berbagai aspek kehidupan harus dapat dinikmati secara adil dan merata oleh segenap bangsa Indonesia diberbagai wilayah (Dokumen RPJMN, 2014).

Kemiskinan merupakan sebuah lingkaran yang tak berujung, selalu berkaitan antara faktor satu dengan yang lain. Pada saat seseorang dengan produksi rendah maka, pendapatan akan rendah pula, dengan begitu akan masuklah kedalam satu posisi dikatakan kemiskinan. Dengan kemiskinan maka konsumsi akan rendah dan apabila konsumsi rendah maka akan dipermasalahkan kesehatan dikarenakan ketidakmampuan dalam hal biaya, kembali lagi pada permasalahan awal yaitu dengan kasehatan yang kurang baik tentu saja produktifitas akan rendah, begitulah seterusnya.

Salah satu visi pembangunan nasional adalah meningkatkan kinerja perekonomian agar mampu menciptakan lapangan kerja dan menata kehidupan yang layak bagi seluruh rakyat dan misi pembangunan adalah mewujudkan Indonesia yang sejahtera dengan salah satu sasaran pokok menurunkan jumlah penduduk miskin, dengan mengetahui beberapa besar kemiskinan telah berkurang dapat dilihat juga seberapa besar pembangunan yang dilaksanakan membawa perubahan kondisi hidup masyarakat kearah yang lebih baik dan ini merupakan salah satu tujuan pembangunan.

Kemiskinan merupakan masalah yang komplek dan terjadi diberbagai tempat diIndonesia. Penanggulangannya kemiskinan sudah banyak dilakukan baik itu oleh lembaga pemerintahan maupun lembaga-lembaga lainnya, akan tetapi hasilnya belum optimal. Penanggulangannya dilakukan selama ini hanya terbatas pada gejala permasalahan saja. Perlu direnungkan, penyebab utamanya kemiskinan (akar permasalahannya), karena apabila akarnya tidak pernah dibabat persoalan ini tak akan pernah selesai.

Masalah kemiskinan terjadi diberbagai tempat di Indonesia termasuk Provinsi Jambi. Masalah kemiskinan di Provinsi Jambi dapat dilihat dari tiga indikator, yang pertama adalah tingkat kemiskinan, yang kedua adalah indeks kedalaman kemiskinan yang terakhir adalah indeks keparahan kemiskinan. Tingkat kemiskinan merupakan perkembangan jumlah penduduk miskin tahun sekarang dibanding tahun sebelumnya. Indeks kedalaman kemiskinan merupakan ukuran rata-rata kesenjangan pengeluaran masing-masing penduduk miskin terhadap garis kemiskinan. Sedangkan indeks keparahan kemiskinan merupakan penyebaran pengeluaran diantara penduduk miskin. Dengan tiga indikator diatas kita dapat melihat bagaimana kondisi kemiskinan yang ada 
dikabupaten/kota Provinsi Jambi, kondisi kemiskinan kabupaten/kota di Provinsi Jambi dapat dilihat pada tabel berikut :

Tabel 1. Jumlah penduduk miskin, indeks kedalaman dan indeks keparahan kemiskinan Kabupaten/Kota Provinsi Jambi Tahun 2017

\begin{tabular}{lrrr}
\hline \multicolumn{1}{c}{ Kabupaten/Kota } & $\begin{array}{c}\text { Penduduk } \\
\text { Miskin } \\
\text { 2017 }\end{array}$ & $\begin{array}{c}\text { Kedalaman } \\
\text { Kemiskinan } \\
\mathbf{2 0 1 7}\end{array}$ & $\begin{array}{c}\text { Keparahan } \\
\text { Kemiskinan } \\
\text { 2017 }\end{array}$ \\
\hline Kerinci & 17.620 & 1,56 & 0,51 \\
Merangin & 35.480 & 1,69 & 0,52 \\
Sarolangun & 25.610 & 2,20 & 0,69 \\
Batanghari & 27.490 & 1,86 & 0,51 \\
Muaro Jambi & 18.280 & 0,45 & 0,07 \\
Tanjab Timur & 27.220 & 2,98 & 1,05 \\
Tanjab Barat & 36.330 & 2,35 & 0,67 \\
Tebo & 23.180 & 0,87 & 0,19 \\
Bungo & 20.810 & 1,19 & 0,29 \\
Kota Jambi & 52.080 & 1,13 & 0,27 \\
Kota Sungai Penuh & 2.460 & 0,23 & 0,03 \\
Provinsi Jambi & 286.560 & 1,50 & 0,44 \\
\hline
\end{tabular}

Sumber: Badan Pusat Statistik, 2019 (diolah)

Berdasarkan Tabel 1 bahwa jumlah penduduk miskin di Provinsi Jambi Tahun 2017 sebesar 286.560 persen, indeks kedalaman kemiskinan sebesar 1,50 persen dan indeks keparahan kemiskinan sebesar 0,44. Selanjutnya indikator kemiskinan Kabupaten Sarolangun berada pada urutan ke-empat. Tahun 2017, jumlah penduduk miskin Kabupaten Sarolangun sebesar 25.610 yang merupakan tingkat kemiskinan terbesar ke-empat dalam Provinsi Jambi, indeks kedalaman kemiskinan 2,20 persen lebih besar dibandingkan dengan indeks kedalaman Provinsi Jambi yang hanya 1,50 persen, untuk indeks keparahan kemiskinan sebesar 0,69 persen, angka tersebut lebih besar dibandingkan dengan indeks keparahan kemiskinan Provinsi Jambi.

Masalah utama yang dihadapi perekonomian Kabupaten Sarolangun adalah bagaimana pembangunan dapat dijalankan dengan tetap mempertahankan kestabilan ekonomi yang sudah dicapai. Pertumbuhan ekonomi tercapai apabila terdapat peningkatan perbandingan antara output dan input yang lebih besar serta adanya perkembangan ekonomi, jadi adanya kenaikan output persatuan input atau setiap kesatuan input dapat menghasilkan output yang lebih besar. Ini artinya peningkatan efisiensi dan peningkatan produktifitas.

Pertumbuhan ekonomi yang tinggi dan berkelanjutan merupakan kondisi utama atau suatu keharusan bagi kelangsungan pembangunan ekonomi dan meningkatkan kesejahteraan, karena jumlah penduduk bertambah setiap tahunnya, maka di butuhkan penambahan pendapatan setiap tahunnya. Pertumbuhan ekonomi tanpa dibarengi dengan penambahan kesempatan kerja akan mengakibatkan ketimpangan dalam pembagian dari penambahan pendapatan tersebut yang selanjutnya akan menciptakan suatu kondisi pertumbuhan ekonomi dengan pertumbuhan ekonomi yang menimbulkan suatu realita yakni peningkatan kemiskinan (Tambunan, 2009). 
Pertumbuhan ekonomi merupakan syarat keharusan dalam pengurangan angka kemiskinan, dengan ciri-ciri pertumbuhan ekonomi tersebut hendaknya menyebar disetiap golongan penduduk miskin. Pertumbuhan ekonomi juga dapat secara langsung mengurangi kemiskinan apabila terjadinya disektor-sektor dimana penduduk miskin bekerja dan juga dapat secara tidak langsung melalui peranan pemerintah yang cukup efektif meretribusi manfaat pertumbuhan pada sektor modern seperti jasa dan manufaktur yang padat modal.

Sebagai salah satu indikator keberhasilan dalam pembangunan, apabila pertumbuhan ekonomi di suatu wilayah semakin tinggi maka daerah tersebut dapat dikatakan berhasil dalam pertumbuhan. Terutama PDRB sektoral ekonomi, pertumbuhan ekonomi tersebut merupakan laju pertumbuhan yang dibentuk dari berbagai sektor ekonomi, yang secara tidak langsung menggambarkan tingkat perubahan ekonomi yang terjadi. Pertumbuhan ekonomi diharapkan mampu meningkatkan pendapatan masyarakat dan pemerataan pembangunan serta hasilhasilnya. Sehingga untuk mengkonkritkan langkah dan kebijakan pemerintah dalam usaha melibatkan serta meratakan seluruh daerah dalam kegiatan-kegiatan pembangunan daerah berdasarkan potensi yang ada didaerah tersebut, (Tan, 2010).

Dibandingkan dengan rata-rata pertumbuhan ekonomi di Provinsi Jambi, angka rata-rata pertumbuhan ekonomi di Kabupaten Sarolangun dinilai rendah dan tidak sesuai dengan penurunan tingkat kemiskinan yang terjadi di Kabupaten Sarolangun setiap tahunnya. Peningkatan pertumbuhan ekonomi mencerminkan peningkatan produksi masing-masing sektor ekonomi. Peningkatan produksi diharapkan memberikan dampak positif bagi peningkatan kesejahteraan masyarakat dan daerah melalui peningkatan penyerapan tenaga kerja.

Penyerapan tenaga kerja di Kabupaten Sarolangun dari total 9 sektor ekonomi selama 5 tahun terakhir yaitu tahun 2013-2017 terus mengalami peningkatan. Pada tahun 2013 jumlah tenaga kerja yang terserap sebesar 130.635 jiwa kemudian menurun di tahun 2014 menjadi sejumlah 120.786 jiwa. Begitu juga pada tahun 2015 dan 2016 jumlah orang bekerja atau penyerapan tenaga kerja di Kabupaten Sarolangun masingmasing sebesar 130.586 jiwa dan 140.386 jiwa serta untuk tahun 2017 penyerapan tenaga kerja di Kabupaten Sarolangun sebesar 139.970 jiwa. Peningkatan penyerapan tenaga kerja memberikan makna angka pengangguran yang menurun. Ketika lebih banyak orang yang bekerja dan memperoleh penghasilan maka pada akhirnya akan menuju pada perbaikan kesejahteraan masyarakat yang diukur dari pendapatan rata-rata penduduk.

Besarnya pertumbuhan ekonomi dan penyerapan tenaga kerja inilah yang sangat memungkinkan sebagai alat pendorong menurunnya tingkat kemiskinan di Kabupaten Sarolangun. Tingginya pertumbuhan ekonomi dan peningkatan penyerapan tenaga kerja belum tentu diiringi dengan penurunan tingkat kemiskinan, indeks kedalaman kemiskinan dan indeks keparahan kemiskinan. Hal ini tentu menjadi perhatian serius bagi pemerintah daerah Kabupaten Sarolangun untuk menekan laju kemiskinan.

Berdasarkan latar belakang yang telah dikemukakan tersebut, penelitian yang penulis lakukan memiliki tujuan sebagai berikut: (a) Menganalisis pengaruh pertumbuhan ekonomi terhadap penyerapan tenaga kerja di Kabupaten Sarolangun. (b) Menganalisis pengaruh pertumbuhan ekonomi dan penyerapan tenaga kerja terhadap tingkat kemiskinan, kedalaman kemiskinan dan keparahan kemiskinan di Kabupten Sarolangun 


\section{METODE}

\section{Metode analisis data}

Metode analisis yang digunakan dalam penelitian ini adalah analisis deskriptif dan analisis jalur (Path Analysis). Analisis deskriptif berdasarkan pada tinjauan literatur melalui jurnal, working paper, artikel, buku-buku dan hasil penelitian yang berhubungan dengan penelitian ini. Untuk melakukan analisis kuantitatif penulis menggunakan model ekonometrika dimana akan diperoleh hasil dalam bentuk angka untuk mendukung dan memudahkan estimasi dalam melakukan analisis kuantitatif tersebut penulis menggunakan software computer Microsoft excel dan SPSS 22.0.

Metode analisis data dalam penelitian ini menggunakan analisis jalur (path analysis). Analisis ini dilakukan untuk menjawab tujuan penelitian, yaitu untuk menganalisis pengaruh langsung pertumbuhan ekonomi terhadap tenaga kerja dan pengaruh lansung pertumbuhan ekonomi terhadap tingkat kemiskinan, indeks kedalaman kemiskinan dan indeks keparahan kemiskinan serta pengaruh pertumbuhan ekonomi terhadap tingkat kemiskinan, indeks kedalaman kemiskinan dan indeks keparahan kemiskinan melalui tenaga kerja di Kabupaten Sarolangun tahun 2001-2017. Analisis jalur merupakan perluasan dari analisis regresi linier berganda, atau analisis jalur adalah penggunaan analisis regresi untuk menaksir hubungan kausalitas antar variabel yang telah ditetapkan sebelumnya berdasarkan teori (Ghozali, 2011). Model Path Analysis digunakan untuk menganalisis pola hubungan antara variabel yang berbentuk sebab akibat. Dengan demikian dalam model hubungan antara variabel eksogen (Exegonous), dan variabel dependen yang disebut variabel Endogen (Endogonous) (Sugiyono, 2007).

Model Persamaan analisis jalur

$$
\begin{aligned}
& \mathrm{TK}=\beta_{0}+\beta_{1} \mathrm{PE}+\varepsilon_{1} \ldots \ldots \ldots \ldots . . \ldots \\
& \mathrm{PR}=\beta_{0}+\beta_{1} \mathrm{PE}+\varepsilon_{1} \ldots \ldots \ldots \ldots \ldots \\
& \mathrm{IDK}=\beta_{0}+\beta_{1} \mathrm{PE}+\varepsilon_{1} \ldots \ldots \ldots \ldots \ldots \\
& \mathrm{IPK}=\beta_{0}+\beta_{1} \mathrm{PE}+\varepsilon_{1} \ldots \ldots \ldots \ldots \ldots \\
& \mathrm{PR}=\beta_{0}+\beta_{1} \mathrm{PE}+\beta_{2} \mathrm{TK}+\varepsilon_{2} \ldots \\
& \mathrm{IDK}=\beta_{0}+\beta_{1} \mathrm{PE}+\beta_{2} \mathrm{TK}+\varepsilon_{2} . \\
& \mathrm{IPK}=\beta_{0}+\beta_{1} \mathrm{PE}+\beta_{2} \mathrm{TK}+\varepsilon_{2} . .
\end{aligned}
$$

Analisis Jalur ingin menguji persamaan regresi yang melibatkan beberapa variabel eksogen dan endogen sekaligus sehingga memungkinkan pengujian terhadap variabel mediating/intervening atau variabel antara. Disamping itu analisis jalur juga dapat mengukur hubungan langsung antar variabel dalam model maupun hubungan tidak langsung antar variabel dalam model. Hubungan langsung antar variabel eksogen terhadap variabel endogen dapat dilihat pada koefisien beta.Hubungan tidak langsung adalah seberapa besar pengaruh variabel eksogen terhadap variabel endogen melalui variabel intervening atau pemediasi. Pengaruh total dapat diperoleh dengan menjumlahkan hubungan langsung dan tidak langsung (Ghozali, 2008).

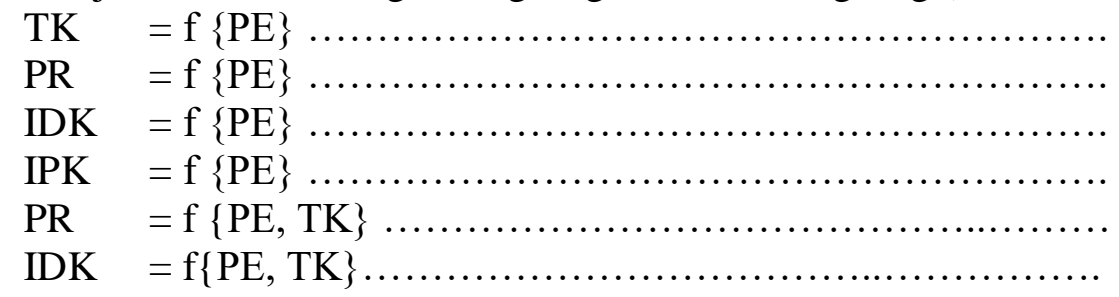


$\mathrm{IPK}=\mathrm{f}\{\mathrm{PE}, \mathrm{TK}\}$

Di mana:

$\begin{array}{ll}\text { TK } & =\text { Tenaga Kerja } \\ \text { PE } & =\text { Pertumbuhan Ekonomi } \\ \text { PR } & =\text { Tingkat Kemiskinan } \\ \text { IDK } & =\text { Indeks Kedalaman Kemiskinan } \\ \text { IPK } & =\text { Indeks Keparahan Kemiskinan } \\ \varepsilon & =\text { Error Term }\end{array}$

\section{Deskriptif variabel penelitian}

\section{Tingkat kemiskinan}

Untuk tingkat kemiskinan di Kabupaten Sarolangun selalu mengalami penurunan setiap tahunnya mulai dari tahun 2001 sampai dengan tahun 2017, kecuali terjadi pada tahun 2011-2015 tingkat kemiskinan mengalami peningkatan dapat dilihat pada Tabel 2 berikut:

Tabel 2. Tingkat kemiskinan dan perkembangannya Kabupaten Sarolangun Tahun $2001-2017$

\begin{tabular}{ccc}
\hline Tahun & Tingkat Kemiskinan & Perkembangan (\%) \\
\hline 2001 & 21,92 & - \\
2002 & 21,88 & $-0,04$ \\
2003 & 20,32 & $-1,56$ \\
2004 & 20,25 & $-0,07$ \\
2005 & 19,81 & $-0,44$ \\
2006 & 18,23 & $-1,58$ \\
2007 & 16,11 & $-2,12$ \\
2008 & 11,69 & $-4,42$ \\
2009 & 9,85 & $-1,84$ \\
2010 & 9,66 & $-0,19$ \\
2011 & 9,1 & $-0,56$ \\
2012 & 9,46 & 0,36 \\
2013 & 9,55 & 0,09 \\
2014 & 10,17 & 0,62 \\
2015 & 10,29 & 0,12 \\
2016 & 9,33 & $-0,96$ \\
2017 & 8,87 & $-0,46$ \\
\hline Sumber: Badan Pusat Statistik Kabupaten Sarolangun 2020 & (diolah).
\end{tabular}

Sumber: Badan Pusat Statistik Kabupaten Sarolangun,2020 (diolah).

Melihat Tabel 2, maka dapat diketahui perkembangan tingkat kemiskinan di Kabupaten Sarolangun. Penurunan tingkat kemiskinan yang paling besar yaitu terjadi pada tahun 2008 sebesar 4,42 persen atau setara dengan 3.410 Jiwa. Sedangkan untuk penurunan tingkat kemiskinan yang paling rendah bahkan terjadi peningkatan tingkat kemiskinan atau bertambahnya penduduk miskin pada tahun 2012, 2013 dan tahun 2014. 


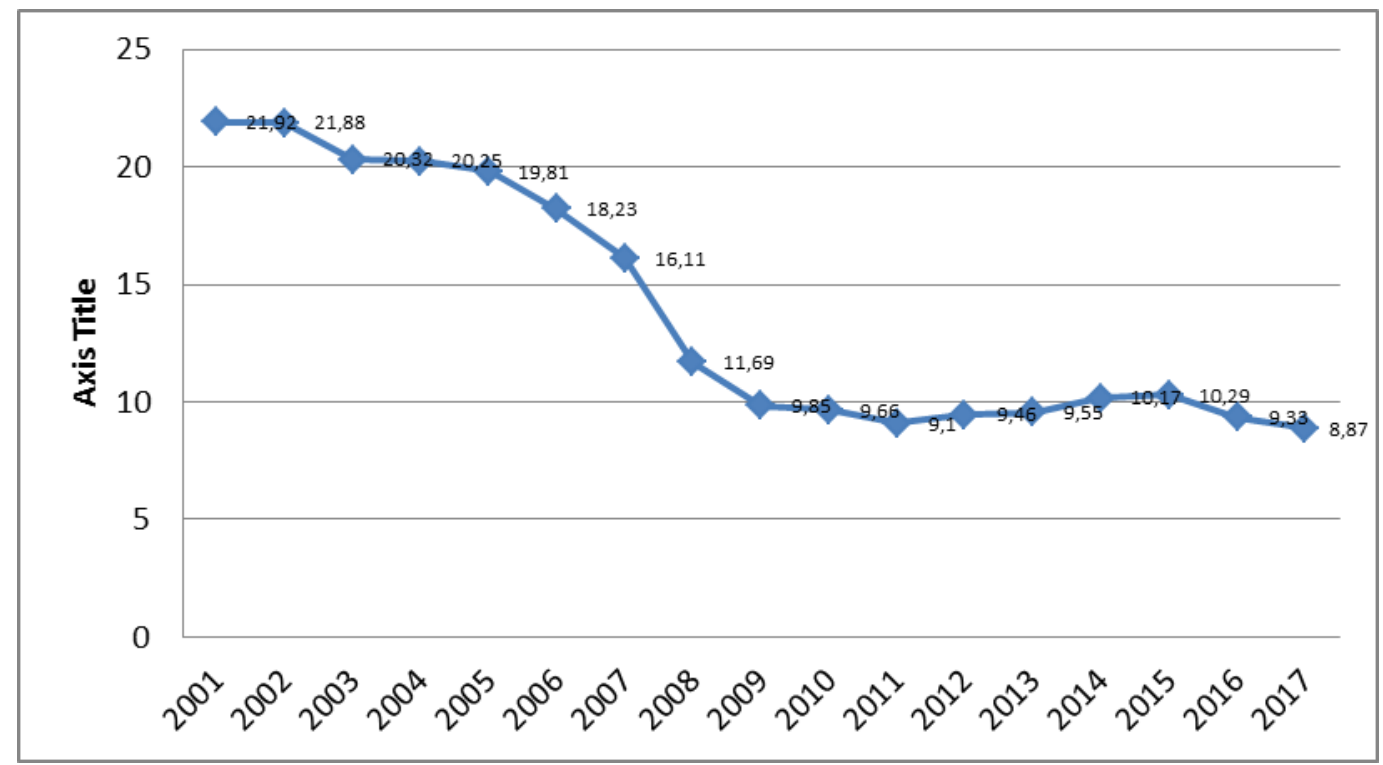

Sumber: Badan Pusat Statistik Kabupaten Sarolangun,2020 (diolah).

Grafik 1. Perkembangan tingkat kemiskinan di Kabupaten Sarolangun, 2001 - 2017

Berdasarkan pada Grafik 1, perkembangan tingkat kemiskinan berfluktuatif dimana pada tahun tahun 2002-2012 mengalami penurunan secara terus menerus dan diikuti pada tahun 2016-2017. Sedangkan pada tahun 2012-2015 terjadi peningkatan tingkat kemiskinan walaupun besarannya berbeda-beda.

Kemiskinan adalah ketidakmampuan penduduk memenuhi standar minimum kebutuhan dasar yang meliputi kebutuhan pangan maupun non pangan. Maksud dari definisi tersebut adalah membandingkan tingkat konsumsi penduduk dengan garis kemiskinan atau jumlah rupiah untuk konsumsi orang perbulan.

\section{Indeks kedalaman dan keparahan kemiskinan}

Indeks kedalaman kemiskinan merupakan ukuran rata-rata kesenjangan pengeluaran masing-masing penduduk miskin terhadap garis kemiskinan. Sedangkan, indeks keparahan kemiskinan memberikan informasi mengenai gambaran penyebaran pengeluaran di antara penduduk miskin.

Berdasarkan Grafik 2 menunjukkan indeks kedalaman kemiskinan Kabupaten Sarolangun berfluktuasi tajam. Pada tahun 2001 berada di angka 3.25 persen kemudian menurun pada tahun berikutnya sebesar 3.03 persen, meningkat kembali pada Tahun 2003 sebesar 4.01 persen dan terus mengalami penurunan hingga mencapai angka 2.46 pada tahun 2007. Pada Tahun 2008 kembali meningkat menyentuh angka 4.61 persen dan terus mengalami penurunan yang signifikan di angka 1 persen hingga tahun 2016 sebesar 1,37 persen dan sebesar 2.2 persen di akhir periode analisis. Sedangkan, indeks keparahan kemiskinan Kabupaten Sarolangun berfluktuasi tajam. Pada tahun 2001 berada di angka 0.47 persen kemudian meningkat pada Tahun 2003 sebesar 1.36 persen dan terus mengalami penurunan hingga mencapai angka 0.61 pada tahun 2007. Pada Tahun 2008 kembali meningkat menyentuh angka 2.02 persen dan terus mengalami penurunan yang signifikan di bawah angka 1 persen hingga tahun 2017 sebesar 0.6 persen.

Semakin tinggi nilai indeks, semakin jauh rata-rata pengeluaran penduduk dari garis kemiskinan. Indeks kedalaman kemiskinan menunjukkan seberapa jauh beda pengeluaran penduduk miskin dari garis kemiskinan. Dengan asumsi garis kemiskinan 
sama, wilayah yang rata-rata warga miskinnya hanya mampu belanja Rp10.000 sehari, misalnya, lebih dalam kemiskinannya dari wilayah yang rata-rata warga miskinnya mampu belanja Rp30.000 sehari.

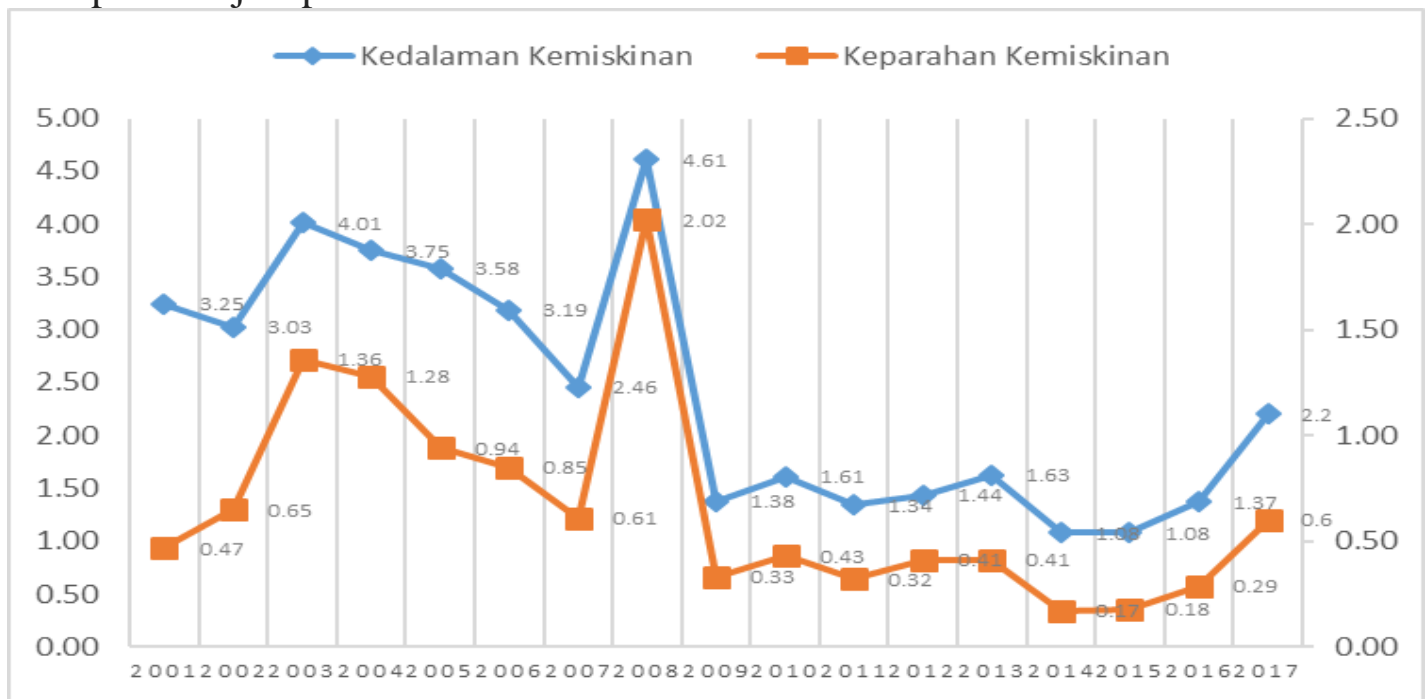

Sumber: Badan Pusat Statistik Kabupaten Sarolangun, 2019

Grafik 2 Indeks kedalaman dan keparahan kemiskinan Kab. Sarolangun, 2001 - 2017

Sedangkan di wilayah yang lebih kecil akan sangat membantu pembuat kebijakan mengalokasikan anggaran lebih efisien.

\section{HASIL DAN PEMBAHASAN}

Pengaruh pertumbuhan ekonomi terhadap penyerapan tenaga kerja

Penelitian ini terdiri atas lima variabel yaitu pertumbuhan ekonomi, tenaga kerja, tingkat kemiskinan, indeks kedalaman kemiskinan dan indeks keparahan kemiskinan Kabupaten Sarolangun. Untuk mengestimasi variabel dalam penelitian ini digunakan model ekonometrika Analisis Jalur (Path). Hasil estimasi model penelitian adalah sebagai berikut:

Tabel 3. Coefficients ${ }^{\mathbf{a}}$

\begin{tabular}{|c|c|c|c|c|c|c|}
\hline & \multirow[t]{2}{*}{ Model } & \multicolumn{2}{|c|}{$\begin{array}{l}\text { Unstandardized } \\
\text { Coefficients }\end{array}$} & \multirow{2}{*}{$\begin{array}{c}\text { Standardized } \\
\text { Coefficients } \\
\text { Beta }\end{array}$} & \multirow[t]{2}{*}{$\mathbf{t}$} & \multirow[t]{2}{*}{ Sig. } \\
\hline & & B & Std. Error & & & \\
\hline \multirow[t]{2}{*}{1} & (Constant) & 106918.646 & 40583.561 & & 2.635 & .019 \\
\hline & Pertumbuhan Ekonomi & -2501.080 & 6020.612 & -.107 & -.415 & .684 \\
\hline
\end{tabular}

a. Dependent Variable: Tenaga Kerja

Sumber: Data diolah, 2020

Berdasarkan Unstandardized Coefficients Beta, maka dirumuskan persamaan model secara umum sebagai berikut :

$\mathrm{TK}_{\mathrm{t}}=106918.646+-2501.080 \mathrm{PE}_{t}+\mathrm{e}_{t}$

t- stat (2.635) (0.415)

p-value [0.019] [0.684]

Dari hasil persamaan diatas, terlihat bahwa variabel pertumbuhan ekonomi tidak berpengaruh signifikan terhadap variabel terikat tenaga kerja. Setiap peningkatan 1 
persen pada pertumbuhan ekonomi, tidak berpengaruh terhadap bertambah atau berkurangnya jumlah tenaga kerja di Kabupaten Sarolangun.

Tenaga kerja di Kabupaten Sarolangun tidak semua berasal dari Kabupaten Sarolangun itu sendiri, melainkan dari luar Kabupaten Sarolangun, dan sebagian bekerja atau ditempatkan tidak sesuai dengan pendidikan dan keterampilan masing-masing, sehingga tenaga kerja tidak signifikan terhadap pertumbuhan ekonomi. Dalam pandangan Ravenstein migrasi (proses mobilitas penduduk) ini terjadi secara spasial dan relatif permanen. Akan tetapi ia berpandangan bahwa dalam situasi ekonomi yang terus berkembang dan disertai dengan meningkatnya sarana dan prasarana transportasi yang semakin baik, arus mobilitas penduduk cenderung menunjukkan gerak yang sifatnya berulang-ulang. Mobilitas semacam ini banyak terjadi antara daerah kota yang pekerjapekerjaannya berulang alik dari tempat tinggal ke tempat kerjanya yang dilakukan secara terus menerus.

Lewis dengan hasil studinya tentang mekanisme mobilitas tenaga kerja dari sektor pedesaan yang subsisten ke sektor perkotaan yang mempunyai tingkat upah yang lebih tinggi. Dia mengganggap bahwa daerah pedesaan yang surplus (dan bahkan produk marjinalnya bisa dikatakan nol) akan berpindah ke daerah pusat industri atau perdagangan yang membutuhkan tenaga kerja. Dampak negatif dari terjadinya migrasi yaitu terjadinya tingkat migrasi yang tidak seimbang (antara migrasi masuk dan migrasi keluar). Selain itu jika terjadi berbagai masalah kependudukan lain terkait berlebihannya jumlah urban di suatu kota akibatnya pembangunan suatu daerah terhambat dan produktivitas menurun karena minimnya tenaga kerja produktif karena penduduk yang melakukan migrasi dari desa ke kota tersebut tidak cukup berkualitas. Akibatnya mereka malah menambah beban bagi kota-kota yang didatangi berupa kemacetan lalu lintas, kekumuhan, kewajiban bagi pemerintah untuk menyediakan berbagai prasarana seperti air minum, listrik dll.

Hasil peneltian ini sejalan dengan hasil penelitian yang dilakukan oleh Rafika Mokodompis yang melakukan penelitian dengan judul "Pengaruh Investasi, Tenaga Kerja terhadap Pertumbuhan Ekonomi di Kota Manado. Hasil dari penelitian ini adalah variabel investasi berpengaruh signifikan, sedangkan tenaga kerja tidak berpengaruh signifikan terhadap pertumbuhan ekonomi di Kota Manado. Todaro menyebutkan bahwa pertumbuhan penduduk dan pertumbuhan tenaga kerja secara tradisional dianggap sebagai salah satu faktor positif yang memacu pertumbuhan ekonomi. Jumlah tenaga kerja yang lebih besar berarti akan menambah tingkat produksi, sedangkan pertumbuhan penduduk yang lebih besar berarti ukuran pasar domestiknya lebih besar. Selanjutnya dikatakan bahwa pengaruh positif atau negatif dari pertumbuhan penduduk tergantung pada kemampuan sistem perekonomian daerah tersebut dalam menyerap dan secara produktif memanfaatkan pertambahan tenaga kerja tersebut. Kemampuan tersebut dipengaruhi oleh tingkat dan jenis akumulasi modal dan tersedianya input dan faktor penunjang seperti kecakapan manajerial dan administrasi. Pada uji ketepatan model atau pengujian uji kesesuaian dilakukan untuk menentukan kelayakan suatu model regresi, dapat dilihat dari nilai $\mathrm{R}$ square.

Tabel 4. Model summary

\begin{tabular}{lcccr}
\hline Model & R & R Square & Adjusted R Square & $\begin{array}{c}\text { Std. Error of the } \\
\text { Estimate }\end{array}$ \\
\hline 1 & $.107^{\mathrm{a}}$ & .011 & -.055 & 40999.62899 \\
\hline a. Predictors: (Constant), Pertumbuhan Ekonomi & & \\
Sumber: Data diolah, 2020 & & &
\end{tabular}


Besarnya nilai $\mathrm{R}^{2}$ yang terdapat pada Tabel 4 adalah sebesar 0.011 , hal ini menunjukkan bahwa kontribusi atau sumbangan pengaruh pertumbuhan ekonomi terhadap tenaga kerja di Kabupaten Sarolangun hanya sebesar 1 persen, sementara sisanya sebesar 99 persen merupakan kontribusi dari variabel-variabel lain yang tidak dimasukkan dalam penelitian.

Pengaruh pertumbuhan ekonomi dan tenaga kerja terhadap tingkat kemiskinan, kedalaman kemiskinan dan keparahan kemiskinan

Berdasarkan hasil penelitian diatas selanjutnya dilakukan pengujian pengaruh langsung pertumbuhan ekonomi terhadap tingkat kemiskinan melalui tenaga kerja. Hasil estimasi model penelitian adalah sebagai berikut:

Tabel 5. Coefficients ${ }^{a}$

\begin{tabular}{|c|c|c|c|c|c|c|}
\hline & \multirow{2}{*}{ Model } & \multicolumn{2}{|c|}{$\begin{array}{l}\text { Unstandardized } \\
\text { Coefficients }\end{array}$} & \multirow{2}{*}{$\begin{array}{c}\begin{array}{c}\text { Standardized } \\
\text { Coefficients }\end{array} \\
\text { Beta } \\
\end{array}$} & \multirow{2}{*}{$\mathbf{t}$} & \multirow{2}{*}{ Sig. } \\
\hline & & B & $\begin{array}{c}\text { Std. } \\
\text { Error }\end{array}$ & & & \\
\hline \multirow[t]{3}{*}{1} & (Constant) & 84.77082 & 39.02759 & & 2.172 & .000 \\
\hline & $\begin{array}{l}\text { Pertumbuhan } \\
\text { Ekonomi }\end{array}$ & -0.074168 & .038 & -.311 & -1.929 & .011 \\
\hline & Tenaga Kerja & -0.096807 & .033 & -.896 & -2.853 & .012 \\
\hline
\end{tabular}

a. Dependent Variable: Tingkat Kemiskinan

Sumber: Data diolah, 2020

Persamaan model secara umum sebagai berikut :

$P R_{t}=84.77082-1.741 P E_{t}-2.968 T K_{t}+0.40 e_{t}$

t- stat $(2.172) \quad(1.92) \quad(2.85)$

$\mathrm{p}$-value $[0.000] \quad[0.011] \quad[0.012]$

Berdasarkan Tabel 5 dapat diketahui nilai signifikansi variabel pertumbuhan ekonomi dan tenaga kerja masing - masing sebesar 0.011 dan 0.012 lebih kecil dari tingkat signifikansi $\alpha=0,05$. Hasil ini memberikan kesimpulan bahwa variabel tenaga kerja dan pertumbuhan ekonomi berpengaruh signifikan terhadap tingkat kemiskinan.

Berdasarkan hasil pengujian didapatkan nilai koefisien regresi pertumbuhan ekonomi sebesar minus 0.074168 , yang berarti bahwa setiap peningkatan pada pertumbuhan ekonomi di Kabupaten Sarolangun sebesar 1 persen, maka akan menurunkan tingkat kemiskinan Kabupaten Sarolangun sebesar 0.074168 persen. Nilai koefisien regresi tenaga kerja sebesar minus 0.096807, yang berarti bahwa setiap penambahan tenaga kerja sebesar 1 orang di Kabupaten Sarolangun, maka akan mengurangi tingkat kemiskinan 0.096807 persen.

Tabel 6. Model summary

\begin{tabular}{ccccc}
\hline Model & R & R Square & Adjusted R Square & $\begin{array}{c}\text { Std. Error of the } \\
\text { Estimate }\end{array}$ \\
\hline 1 & $.916^{\mathrm{a}}$ & .840 & .817 & 2965.04917 \\
\hline
\end{tabular}

a. Predictors: (Constant), Tenaga Kerja, Pertumbuhan Ekonomi

Sumber: Data diolah, 2020 
Besarnya nilai $\mathrm{R}^{2}$ yang terdapat pada tabel 5.4 adalah sebesar 0.840 , hal ini menunjukkan bahwa kontribusi atau sumbangan pengaruh tenaga kerja dan pertumbuhan ekonomi terhadap tingkat kemiskinan adalah sebesar 84 persen, sementara sisanya sebesar 16 persen merupakan kontribusi dari variabel-variabel lain yang tidak dimasukkan dalam penelitian. Nilai error term dapat dicari dengan rumus:

$$
\mathbf{e}_{1}=\sqrt{ }(\mathbf{1 - 0 , 8 4 0 )}=\mathbf{0 , 4 0}
$$

Berdasarkan Standardized Coefficients Beta pertumbuhan ekonomi sebesar minus 0.311 dan tenaga kerja sebesar minus 0.896 , maka dirumuskan diagram jalur sebagai berikut sebagai berikut:

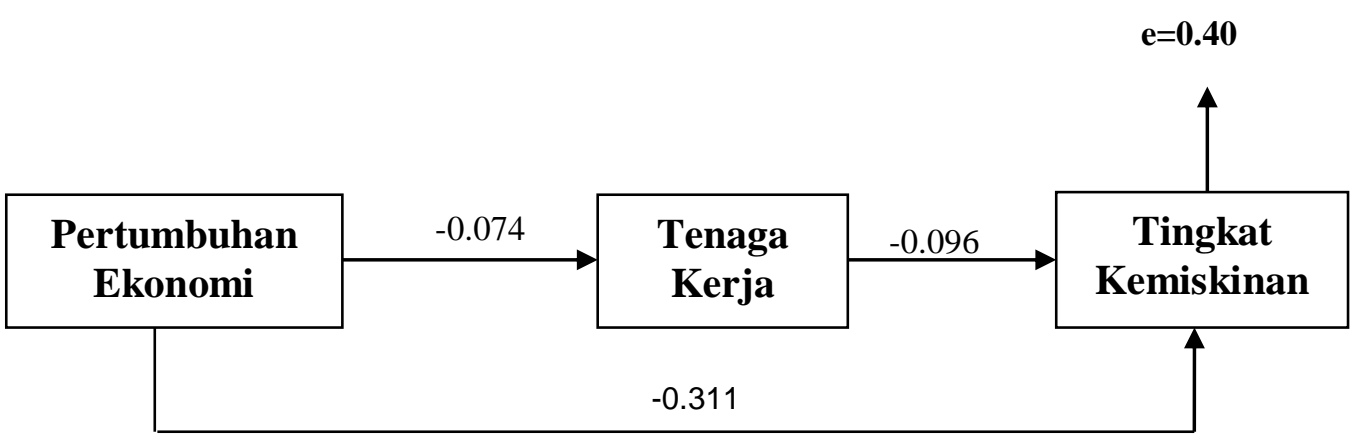

Sumber: Data diolah, 2020

Dari nilai standardized beta dalam Pengujian nilai coefficients pertumbuhan ekonomi terhadap tingkat kemiskinan adalah sebesar minus 0.311 dengan tingkat signifikan 0.011 yang berarti variabel pertumbuhan ekonomi secara langsung berpengaruh terhadap tingkat kemiskinan Kabupaten Sarolangun melalui tenaga kerja.

Berdasarkan hasil penelitian diatas selanjutnya dilakukan pengujian pengaruh langsung pertumbuhan ekonomi terhadap tingkat kedalaman kemiskinan melalui tenaga kerja. Hasil estimasi model penelitian adalah sebagai berikut:

Tabel 7. Coefficients ${ }^{\mathrm{a}}$

\begin{tabular}{|c|c|c|c|c|c|c|}
\hline & \multirow[t]{2}{*}{ Model } & \multicolumn{2}{|c|}{$\begin{array}{l}\text { Unstandardized } \\
\text { Coefficients }\end{array}$} & \multirow{2}{*}{$\begin{array}{c}\begin{array}{c}\text { Standardized } \\
\text { Coefficients }\end{array} \\
\text { Beta }\end{array}$} & \multirow[t]{2}{*}{$\mathbf{t}$} & \multirow[t]{2}{*}{ Sig. } \\
\hline & & B & Std. Error & & & \\
\hline \multirow[t]{3}{*}{1} & (Constant) & 4.687 & .933 & & 5.026 & .000 \\
\hline & $\begin{array}{l}\text { Pertumbuhan } \\
\text { Ekonomi }\end{array}$ & -.036 & .011 & -.053 & -3.130 & .001 \\
\hline & Tenaga Kerja & $0.00002254^{-}$ & .000 & -.779 & -4.594 & .000 \\
\hline
\end{tabular}

a. Dependent variable: indeks kedalaman kemiskinan

Sumber: Data diolah, 2020

Persamaan model secara umum sebagai berikut :

$\mathrm{IDK}_{\mathrm{t}}=4.687-0.036 \mathrm{PE}_{\mathrm{t}}-0.00002254 \mathrm{TK}_{\mathrm{t}}+0.398 \mathrm{e}_{\mathrm{t}}$

t- stat $(5.026)$

p-value [0.000]

[0.001]

[0.000] 
Berdasarkan Tabel 7 dapat diketahui nilai signifikansi variabel pertumbuhan ekonomi dan tenaga kerja masing - masing sebesar 0.001 dan 0.000 lebih kecil dari tingkat signifikansi $\alpha=0,05$. Hasil ini memberikan kesimpulan bahwa variabel tenaga kerja dan pertumbuhan ekonomi berpengaruh signifikan terhadap tingkat kedalaman kemiskinan.

Berdasarkan hasil pengujian didapatkan nilai koefisien regresi pertumbuhan ekonomi sebesar minus 0.036, yang berarti bahwa setiap peningkatan pada pertumbuhan ekonomi di Kabupaten Sarolangun sebesar 1 persen, maka akan menurunkan tingkat kedalaman kemiskinan Kabupaten Sarolangun sebesar 0.036 persen. Nilai koefisien regresi tenaga kerja sebesar minus 0.00002254 , yang berarti bahwa setiap penambahan tenaga kerja sebesar 1 orang di Kabupaten Sarolangun, maka akan menurunkan tingkat kedalaman kemiskinan sebesar 0.00002254 persen.

Tabel 8. Model summary

\section{Model R R Square Adjusted R Square Std. Error of the Estimate}

\begin{tabular}{lllll}
\hline 1 & $.776^{\mathrm{a}}$ & .602 & .545 & .77898 \\
\hline
\end{tabular}

a. Predictors: (Constant), Tenaga Kerja, Pertumbuhan Ekonomi

Sumber: Data diolah, 2020

Besarnya nilai $\mathrm{R}^{2}$ yang terdapat pada Tabel 8 adalah sebesar 0.602 , hal ini menunjukkan bahwa kontribusi atau sumbangan pengaruh tenaga kerja dan pertumbuhan ekonomi terhadap tingkat kedalaman kemiskinan adalah sebesar 60.2 persen, sementara sisanya sebesar 39.8 persen merupakan kontribusi dari variabelvariabel lain yang tidak dimasukkan dalam penelitian. Nilai error term dapat dicari dengan rumus:

$$
\mathbf{e}_{1}=\sqrt{ }(\mathbf{1 - 0 , 6 0 1 )}=\mathbf{0 , 3 9 8}
$$

Berdasarkan Standardized Coefficients Beta pertumbuhan ekonomi sebesar minus 0.053 dan tenaga kerja sebesar minus 0.779 , maka dirumuskan diagram jalur sebagai berikut sebagai berikut:

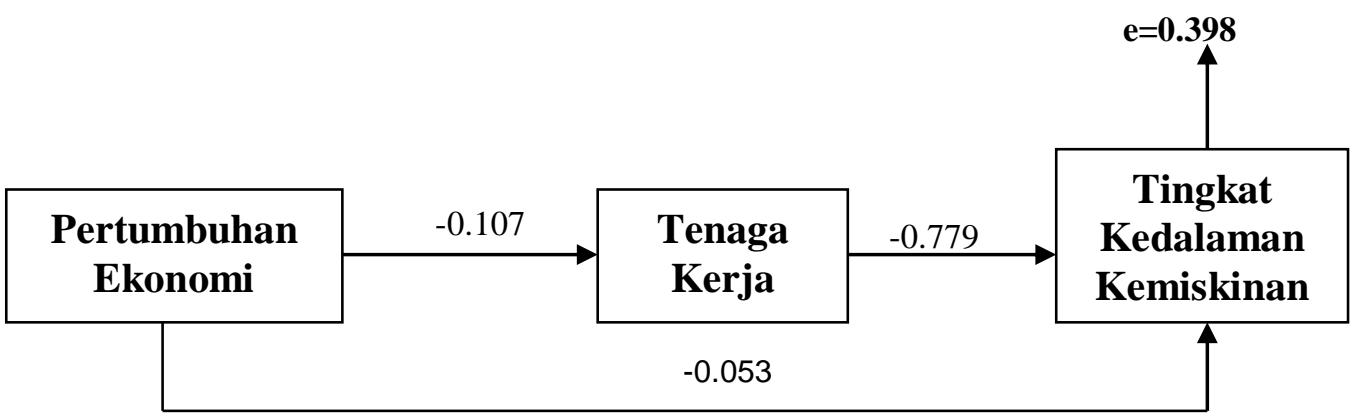

Sumber: Data diolah, 2020

Dari nilai standardized beta dalam Pengujian nilai coefficients pertumbuhan ekonomi terhadap tingkat kedalaman kemiskinan adalah sebesar minus 0.053 dengan tingkat signifikan 0.001 yang berarti variabel pertumbuhan ekonomi secara langsung 
berpengaruh terhadap tingkat kedalaman kemiskinan Kabupaten Sarolangun melalui tenaga kerja.

Berdasarkan hasil penelitian diatas selanjutnya dilakukan pengujian pengaruh langsung pertumbuhan ekonomi terhadap tingkat keparahan kemiskinan melalui tenaga kerja. Hasil estimasi model penelitian adalah sebagai berikut:

Tabel 9. Coefficients ${ }^{\mathrm{a}}$

\begin{tabular}{|c|c|c|c|c|c|c|}
\hline & \multirow[t]{2}{*}{ Model } & \multicolumn{2}{|c|}{$\begin{array}{l}\text { Unstandardized } \\
\text { Coefficients }\end{array}$} & \multirow{2}{*}{$\begin{array}{c}\begin{array}{c}\text { Standardized } \\
\text { Coefficients }\end{array} \\
\text { Beta }\end{array}$} & \multirow[t]{2}{*}{$\mathbf{t}$} & \multirow[t]{2}{*}{ Sig. } \\
\hline & & B & Std. Error & & & \\
\hline \multirow[t]{3}{*}{1} & (Constant) & 1.249 & .543 & & 2.299 & .037 \\
\hline & $\begin{array}{l}\text { Pertumbuhan } \\
\text { Ekonomi }\end{array}$ & -.002 & .000 & -.007 & -2.985 & .047 \\
\hline & Tenaga Kerja & -0.000006295 & .000 & -.510 & -2.203 & .045 \\
\hline
\end{tabular}

a. Dependent Variable: Indeks Keparahan Kemiskinan

Sumber: Data diolah, 2020

Persamaan model secara umum sebagai berikut :

$I K_{t}=1.249-0.002 P E_{t}-0.000006295 T K_{t}+0.741 e_{t}$
t- stat (2.299)
(2.985)
(2.203)
p-value [0.037]
[0.047]
[0.045]

Berdasarkan Tabel 9 dapat diketahui nilai signifikansi variabel pertumbuhan ekonomi dan tenaga kerja masing - masing sebesar 0.047 dan 0.045 lebih kecil dari tingkat signifikansi $\alpha=0,05$. Hasil ini memberikan kesimpulan bahwa variabel tenaga kerja dan pertumbuhan ekonomi berpengaruh signifikan terhadap tingkat keparahan kemiskinan.

Berdasarkan hasil pengujian didapatkan nilai koefisien regresi pertumbuhan ekonomi sebesar minus 0.002, yang berarti bahwa setiap peningkatan pada pertumbuhan ekonomi di Kabupaten Sarolangun sebesar 1 persen, maka akan menurunkan tingkat keparahan kemiskinan Kabupaten Sarolangun sebesar 0.002 persen. Nilai koefisien regresi tenaga kerja sebesar minus 0.000006295 , yang berarti bahwa setiap penambahan tenaga kerja sebesar 1 orang di Kabupaten Sarolangun, maka akan menurunkan tingkat kedalaman kemiskinan sebesar 0.000006295 persen.

Tabel 10. Model summary

\begin{tabular}{lrrrr}
\multicolumn{1}{c}{ Model } & R & R Square & Adjusted R Square & \multicolumn{2}{c}{$\begin{array}{c}\text { Std. Error of the } \\
\text { Estimate }\end{array}$} \\
\hline 1 & \multicolumn{2}{c}{.259} & .153 & .45371 \\
\hline a. Predictors: (Constant), Tenaga Kerja, Pertumbuhan Ekonomi &
\end{tabular}

Sumber: Data diolah, 2020

Besarnya nilai $\mathrm{R}^{2}$ yang terdapat pada Tabel 10 adalah sebesar 0.259 , hal ini menunjukkan bahwa kontribusi atau sumbangan pengaruh tenaga kerja dan pertumbuhan ekonomi terhadap tingkat keparahan kemiskinan hanya sebesar 25.9 persen, sementara sisanya sebesar 74.1 persen merupakan kontribusi dari variabel- 
variabel lain yang tidak dimasukkan dalam penelitian. Nilai error term dapat dicari dengan rumus:

$$
e_{1}=\sqrt{ }(1-0,259)=0,741
$$

Berdasarkan Standardized Coefficients Beta pertumbuhan ekonomi sebesar minus 0.007 dan tenaga kerja sebesar minus 0.510 , maka dirumuskan diagram jalur sebagai berikut sebagai berikut:

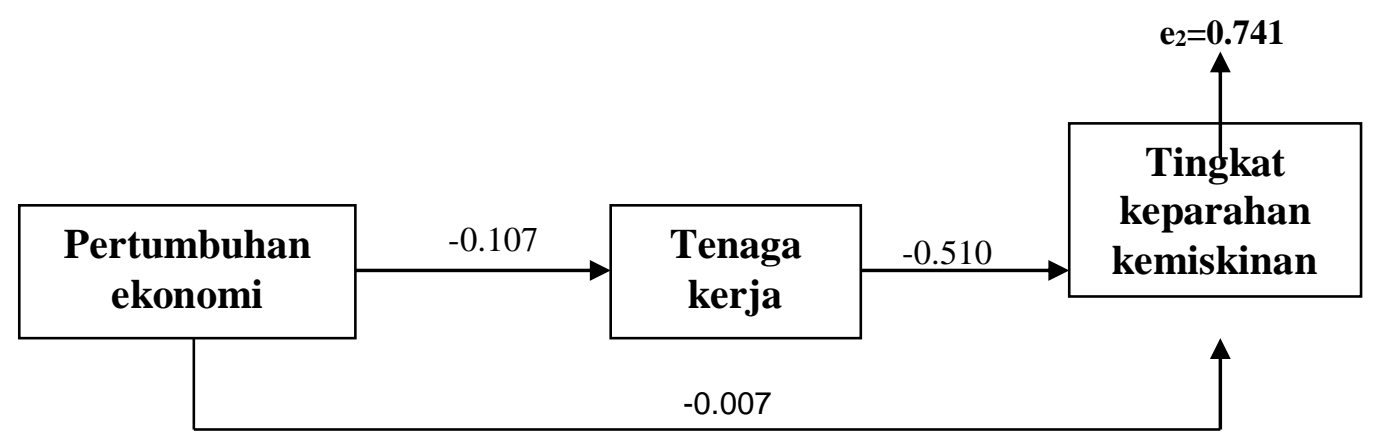

Sumber: Data diolah, 2020

Dari nilai standardized beta dalam Pengujian nilai coefficients pertumbuhan ekonomi terhadap tingkat keparahan kemiskinan adalah sebesar minus 0.007 dengan tingkat signifikan 0.047 yang berarti variabel pertumbuhan ekonomi secara langsung berpengaruh terhadap tingkat keparahan kemiskinan Kabupaten Sarolangun melalui tenaga kerja.

\section{KESIMPULAN DAN SARAN}

\section{Kesimpulan}

Pertumbuhan ekonomi tidak berpengaruh signifikan terhadap variabel terikat tenaga kerja. Setiap peningkatan atau penurunan pada pertumbuhan ekonomi, tidak berpengaruh terhadap bertambah atau berkurangnya jumlah tenaga kerja di Kabupaten Sarolangun.

Pertumbuhan ekonomi memiliki arah yang negatif dan berpengaruh signifikan terhadap tingkat kemiskinan, kedalaman kemiskinan dan keparahan kemiskinan melalui tenaga kerja pada Kabupaten Sarolangun. Setiap peningkatan pada pertumbuhan ekonomi di Kabupaten Sarolangun sebesar 1 persen, maka akan menurunkan tingkat kemiskinan Kabupaten Sarolangun sebesar 0.074168 persen. Setiap peningkatan pada pertumbuhan ekonomi di Kabupaten Sarolangun sebesar 1 persen, maka akan menurunkan tingkat kedalaman kemiskinan Kabupaten Sarolangun sebesar 0.036 persen. Setiap peningkatan pada pertumbuhan ekonomi di Kabupaten Sarolangun sebesar 1 persen, maka akan menurunkan tingkat keparahan kemiskinan Kabupaten Sarolangun sebesar 0.002 persen.

\section{Saran}

Pada Aspek tenaga kerja, perhatian pemerintah difokuskan pada upaya peningkatan kualitas sumber daya manusia, terutama pada tenaga kerja yang telah terlibat dalam aktivitas perekonomian berupa program peningkatan soft skill dan hard skill yang tentunya akan meningkatkan produktivitas tenaga kerja.

Para pembuat kebijakan diharapkan tidak hanya menekankan aspek kuantitas dari pertumbuhan ekonomi, namun yang terpenting adalah memberikan perhatian yang lebih pada struktur dan kualitas dari pertumbuhan ekonomi itu sendiri. 


\section{DAFTAR PUSTAKA}

Abdul Halim. (2007). Akuntansi Sektor Publik Akuntansi Keuangan Daerah, Edisi Revisi, Salemba Empat: Jakarta

Algifari, Guritno Mangkoesoebroto. (1998). Teori Ekonomi Makro. STIE YKPN: Yogyakarta

Ang, Robert. (2013). Buku Pintar pasar Modal Indonesia edisi 7. Media Soft Indonesia: Jakarta:

Djojohadikusumo, Sumitro. (2006). Perkembangan Pemikiran Ekonomi: Dasar Teori Ekonomi Pertumbuhan dan Ekonomi Pembangunan. PT Pustaka LP3ES Indonesia: Jakarta.

Erlina, Rasdianto. (2013). Akuntansi Keuangan Daerah Berbasis Akrual, Brama Ardian: Medan

Fuglie, Keith.(2012). Introduction to The Special Issue on Agricultural Productivity Growth: A Closer Look At Large, Developing Countries. Journal of Productivity Analysis 33(3), 169-172.

Hadisapoetro, S. (1973). Biaya dan Pendapatan dalam Usahatani. Fakultas Pertanian UGM: Yogyakarta

Hafsah, M. J. (2008). Kemitraan Usaha Konsepsi dan Strategi. Departemen Pertanian. PT. Pustaka Sinar Harapan: Jakarta.

Hardiwan, D., Amir, A., Junaidi, J., \& Delis, A. (2019). The linkages and impact of plantation-based sectors on economy and poverty in Jambi province, Indonesia: Miyazawa's input-output model. Agricultural and Resource Economics: International Scientific E-Journal, 5(3), 5 - 19

Hendarmin. (2012). Pengaruh Belanja Modal Pemerintah Daerah dan Investasi Swasta terhadap Pertumbuhan Ekonomi, Kesempatan Kerja dan Kesejahteraan Masyarakat di Kabupaten/Kota Provinsi Kalimantan Barat, Jurnal Eksos, 8(3), 144-155

Heri Sudarsono (2008). Bank \& Lembaga Keuangan Syari'ah Cetakan ke-2. Ekonisia: Yogyakarta

Jamzani, Sodik (2007). Pengeluaran Pemerintah dan Pertumbuhan Ekonomi Regional : Studi kasus data panel di Indonesia. Jurnal Ekonomi Pembangunan. 12(1),27-36.

Khodijah, Siti. (2018). Analisis PMA dan Pengaruh Terhadap Pertumbuhan Ekonomi di Indonesia. Disertasi. Universitas Jambi: Jambi

Krugman, Paul dan Obstfeld, Maurice. (2004). Ekonomi Internasional Teori dan Kebijakan Harper Collins Publisher. Ahli Bahasa. Dr. Faisal H. Basri, SE MSc, PT Indeks Kelompok Gramedia: Jakarta

Lukman Syamsudin. (2008). Manajemen Keuangan Perusahaan. PT Raja grafindo Persada: Jakarta:

Mangunwidjaja, D dan I. Sailah. (2005). Pengantar Teknologi Pertanian. Penebar Swadaya: Jakarta

Mardiasmo. (2002). Otonomi dan Manajemen Keuangan Daerah. Penerbit ANDI, Yogyakarta.

Mosher, A. T. (1981). Menggerakkan dan Membangun Pertanian: Syarat-syarat Pokok Pembangunandan Modernisasi. Yasaguna: Jakarta.

Nainggolan, Indra Oloan. (2009). Analisis Faktor-Faktor yang Mempengaruhi Kesempatan Kerja Pada Kabupaten/Kota di Provinsi Sumatera Utara. Tesis. Medan: Sekolah Pascasarjana, Universitas Sumatera Utara: Medan

Payaman, J. Simanjuntak. (2001). Pengantar Ekonomi Sumber Daya Manusia. Penerbit 
FE UI: Jakarta

Prawirosentono, Suyadi. (2002). Manajemen Sumber Daya Manusia: Kebijakan Kinerja Karyawan. Edisi 1. Cetakan Kedelapan. BPFE: Yogyakarta

Rufaidah, Erlina, \& Dwi W. Sari. (2013). Analisis Produk Domestik Regional Bruto Sektor Pertanian Dan Hubungannya Dengan Kesempatan Kerja Serta Distribusi Pendapatan Di Provinsi Sumatera Selatan. Jurnal Studi Sosial. 1(4), 1-6

Samuelson, P. A. (1996). Makro Ekonomi. Erlangga: Jakarta

Samuelson, Paul A dan Nordhaus, William D. (2004). Ilmi Makro Ekonomi. PT. Media Edukasi: Jakarta

Soekartawi. (2002). Prinsip Dasar Ekonomi Pertanian, Raja Grafindo:Jakarta.

Sri Rahayu, dkk. (2014). Efektivitas Kombinasi Filtrat Daun Tembakau (Nicotiana tabacum) dan Filtrat Daun Paitan (Thitonia diversifolia) sebagai Pestisida Nabati Hama Walang Sangit (Leptocorisa oratorius) pada Tanaman Padi. Lentera Bio 4 (1), 25-31.

Sudaryanto. (2006). Peningkatan Ketahanan Pangan Melalui Kecukupan Daging Sapi. Proseding Seminar. Universitas Diponegoro: Semarang

Sulistyaningsih, Endang. (1993). Pengembangan Sumber Daya Manusia, CV Izusu Gempita:Jakarta.

Sunargo,S., \& Hastuti, D. (2019). Mengatasi perilaku kerja kontraproduktif melalui peran integratif politik organisasional dan kecerdasan emosional pada era revolusi industri 4.0, Jurnal Paradigma Ekonomika 14 (2), 45-54

Tan, Syamsurijal. (2014). Keuangan dan Manajemen Internasional. Fakultas Ekonomi dan Bisnis. Universitas Jambi: Jambi.

Todaro, Michael P. (2003). Pembangunan Ekonomi di Dunia Ketiga. Alih Bahasa: Aminuddin dan Drs.Mursid. Ghalia Indonesia: Jakarta:

Tulus H. Tambunan. (2005). Perekonomian Indonesia. Penerbit Ghalia: Jakarta

Widodo, Tri. (2006). Perencanaan Pembangunan. Aplikasi Komputer (Era Otonomi Daerah). UUP STIM YKPN: Yogyakarta. 